\title{
Preliminary Study of Renewable Energy System in Maratua Island to Support Maratua be Renewable Energy Iconic Island
}

\author{
Rachmawan Budiarto $^{a}$, Luthfi Zharif ${ }^{a} *$, Atik Nurul Laila ${ }^{a}$, Didit Setyo Pamuji ${ }^{a}$, \\ Fiki Rahmatika Salis ${ }^{\mathrm{a}}$, Zakariya Arif Fikriyadi ${ }^{\mathrm{a}}$ \\ ${ }^{a}$ Department of Engineering Physics, Faculty of Engineering, Universitas Gadjah Mada Jl. Grafika No. 2, Yogyakarta 55281 , Indonesia
}

\begin{abstract}
Maratua Island is a strategic island in Indonesia and has big potential of tourism, but its electrification ratio is merely about $37.03 \%$. The preliminary study was aimed to design hybrid system combining fossil-based energy technology and renewable energy for Maratua Island. The preliminary study applies HOMER version 2.68 beta. HOMER is a computer model that simplifies the task of designing hybrid renewable microgrids, whether remote or attached to a larger grid. The hybrid system with a lowest total of NPC (Net Present Cost) is the system combining diesel powerplant and photovoltaics with battery.
\end{abstract}

Keywords: Electricity; homer; maratua; renewable energy.

\begin{tabular}{|ll}
\hline \multicolumn{2}{l}{ Nomenclature } \\
NPC & Net Present Cost \\
COE & Cost of Electricity \\
h & hour \\
d & day \\
USD & United State Dollar, \$
\end{tabular}

\section{Introduction}

Maratua Island is located in East Kalimantan Province and belongs to Frontier, Outer, and Left behind area. Figure 1 shows the Maratua Island. This $4118.80 \mathrm{~km}^{2}$ [1] island which is located at $2^{\circ} 16.279^{\prime} \mathrm{NL}$ and $118^{\circ} 34.573^{\prime}$ EL has big potential of tourism [2], but its electrification ratio is merely about $37.03 \%$ [3]. This lack of electricity basic infrastructure causes serious challenge in local economy development. This low level of the electrification ratio in Maratua is partly caused by difficulty of geographical condition which burdens PLN to distribute the electricity through its network. So far, the electricity in Maratua is still supplied by diesel generator. However, price of diesel fuel is expensive (IDR $10000 \mathrm{~L}^{-1}$ ) [4]. This high price causes limitation on electricity service to population (3 183 peoples) in Maratua. They receive electricity only at night.

\footnotetext{
* Corresponding author. Tel.: +62 8568664530 .

E-mail address: luthfi.zharif@mail.ugm.ac.id
} 
Indonesia has great renewable energy resources to be developed for electricity supply system. This study elucidated the preliminary study in regards of design of a hybrid power system combining renewable energy and diesel which is able to meet the electricity demand of Maratua Island for $24 \mathrm{~h} \bullet \mathrm{d}^{-1}$ at a level of $2.345 \mathrm{kWh} \bullet$ capita $^{-1}$ - $\mathrm{d}[5]$. Due to inadequate data in tourism and business sector, this paper only gives analysis on electricity system in domestic sector.

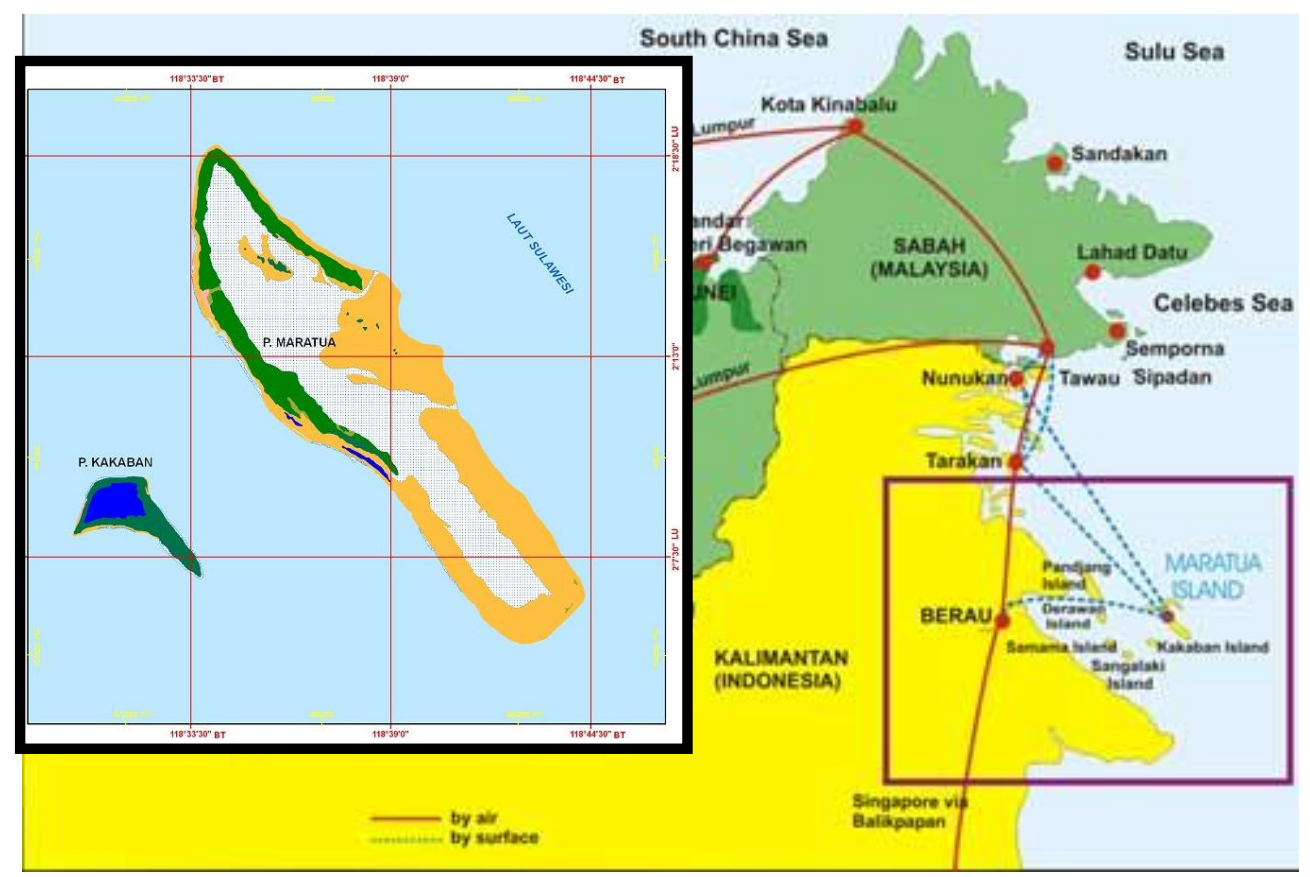

Fig. 1. Maratua Island.

\subsection{Renewable energy potential in Maratua Island}

Development of energy basic infrastructure is also directed to gradually reach energy sovereignty. The World Development Movement defines energy sovereignty as the right of people to have access to energy and to make their own decisions over sustainable energy sources and sustainable consumption patterns. Energy sovereignty gives greater local control of energy resources, with the benefits and returns going to the local or national community. Renewable energy utilization is a vital component in it.

Renewable energy resource which is available in Maratua Island is solar energy. Wind energy cannot be applied due to the low speed of wind, which is merely $2.056 \mathrm{~m}^{-\mathrm{s}^{-1}}$ [6]. Presently, biomass energy cannot be applied due to the lack of adequate animal husbandry and also the lack of suitable natural material to be developed into biomass in an adequate size. Hydro energy cannot also be developed because there is no adequate potential river or waterfall. Probably, Maratua Island has enough wave potential, but presently there is no reliable technology yet to be used in large scale at affordable price.

To predict the renewable energy potential, secondary data was used. Solar energy potential was expressed as daily radiation $\left(\mathrm{kWh} \cdot \mathrm{m}^{-2}\right)$. Table 2 indicated potential energy resources in Maratua Island. The yearly average of radiation is $4.683 \mathrm{kWh} \cdot \mathrm{m}^{-2}[6]$. 


\subsection{Hybrid electric power}

In satisfying the electricity demand, the study simulates a power generator system which is based on available renewable energy resources in Maratua and a diesel powerplant. The diesel powerplant becomes an important component for the power generator system as a support system when renewable energy resources are not available (e.g. solar energy is not available during the night). The hybrid system can provide very high availability and continuity of the service. The other potential advantage using the hybrid system includes for example higher efficiency and low cost in operation [7]. Those properties make the hybrid system could be chosen as a transitional step towards the energy system which relies $100 \%$ on renewable energy resources. Achieving the energy system which relies mainly on the renewable energy could develop Maratua as Renewable Energy Iconic Island.

Table 1. Solar and wind resource in Maratua Island

\begin{tabular}{lcclcc}
\hline \multicolumn{1}{c}{ Month } & $\begin{array}{c}\text { Daily radiation } \\
\left(\mathrm{kWh} \cdot \mathrm{m}^{-2} \cdot \mathrm{d}^{-1}\right)\end{array}$ & Wind speed $\left(\mathrm{m} \cdot \mathrm{s}^{-1}\right)$ & Month & $\begin{array}{r}\text { Daily radiation } \\
\left(\mathrm{kWh} \cdot \mathrm{m}^{-2} \cdot \mathrm{d}^{-1}\right)\end{array}$ & Wind speed $\left(\mathrm{m} \cdot \mathrm{s}^{-1}\right)$ \\
\hline January & 4.216 & 1.028 & July & 4.622 & 2.056 \\
February & 4.631 & 1.542 & August & 4.888 & 2.056 \\
March & 5.022 & 2.056 & September & 5.002 & 2.570 \\
April & 5.102 & 2.056 & October & 4.928 & 2.570 \\
May & 4.576 & 2.056 & November & 4.393 & 2.570 \\
June & 4.622 & 2.056 & December & 4.240 & 2.056 \\
\hline
\end{tabular}

\section{Material and method}

This preliminary study applies HOMER software version 2.68 beta to provide a design of power energy system. The study uses data with the reference year of 2013. It assumes pattern of energy consumption per hour follows a normal distribution with a peak time at 05.00 P.M. to 10.00 P.M., with random variation of $20 \%$ per month, while natural resource's time reference may differ from the other reference time. Pattern of energy consumption per hour was assumed to follow a normal distribution due to lack of adequate actual local data. The pattern was assumed to be representative for energy consumption patterns of Indonesian people in general (see Fig. 2). The data of natural potential with different time references can be accepted because fluctuations of solar radiation and wind speed does not change significantly from year to year. The use of random variation of $20 \%$ was applied to describe the fluctuations in energy usage per month.

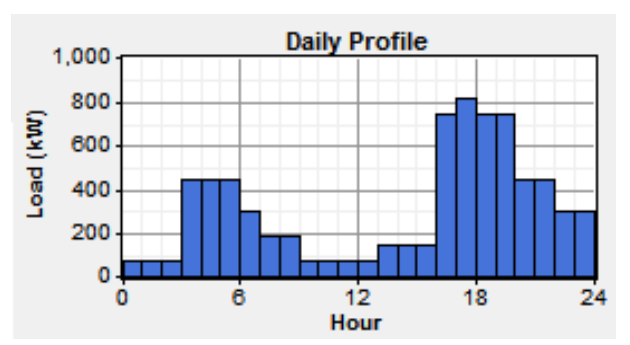

Fig. 2. Energy daily profile.

The simulated hybrid system is built from the diesel powerplant energy, and photovoltaics with variations on installed capacities. The simulation involves mentioned two types of technology, photovoltaics and diesel powerplant. The photovoltaics technology is used due to its relative high level of technology maturity and relative good and constant intensity solar exposure in Indonesia. The diesel powerplant serves as a support system when the power of solar energy system is not enough to fulfill the energy demand in Maratua. 
Power capacity variations of the diesel powerplant to be simulated are $100 \mathrm{~kW}, 500 \mathrm{~kW}, 1 \mathrm{MW}$. Variations of power capacity for solar technology are $500 \mathrm{kWp}$ to $4000 \mathrm{kWp}$. Battery capacity variations are also taken into account due to their influence on optimal power storage. The study also considers economic aspect in choosing the battery. The variations of batteries capacity are 500 to 4000 pieces. The simulation will be carried out in three scenarios. The Scenario 1 uses diesel as a sole energy generation to fulfill the electricity demand in Maratua. The Scenario 2 applies diesel and solar energy with battery as storage of excess energy. The Scenario 3 implements diesel and solar energy without battery due to consideration on high investment and maintenance cost of battery.

The simulation applies data of capital costs as well as operation and maintenance costs of each technology which built the hybrid system. The reference data is presented in Table 2 .

Table 2. Capital, operation and maintenance costs.

\begin{tabular}{lll}
\hline Variable & Solar energy & Diesel energy \\
\hline Capital Cost $\left(\mathrm{USD} \cdot \mathrm{W}^{-1}\right)$ & $0.74[8]$ & 0.38 \\
$\mathrm{O \& M}$ Cost $\left(\mathrm{USD} \cdot \mathrm{kW}^{-1} \cdot\right.$ year $)$ & $27.75[9]$ & $1.2\left(\mathrm{USD} \cdot \mathrm{hour}^{-1}\right)$ \\
\hline
\end{tabular}

\section{Results and discussion}

The HOMER ranks the simulated hybrid systems by total NPC. This value includes all costs and revenues that occur within the project lifetime, with future cash flows discounted to the present. The total net present cost includes the initial capital cost of the system components, the cost of any component replacements that occur within the project lifetime, the cost of maintenance and fuel, and the cost of purchasing power from the grid. Any revenue from the sale of power to the grid reduces the total NPC [10].

(a)

\begin{tabular}{|c|c|c|c|c|c|c|c|c|}
\hline 13 & $\begin{array}{l}\text { Diesl } \\
(\mathrm{kW})\end{array}$ & $\begin{array}{l}\text { Initial } \\
\text { Capital }\end{array}$ & $\begin{array}{c}\text { Operating } \\
\text { Cost (\$/yr) }\end{array}$ & $\begin{array}{l}\text { Total } \\
\text { NPC }\end{array}$ & $\begin{array}{c}\mathrm{COE} \\
(\$ / \mathrm{kWh})\end{array}$ & $\begin{array}{l}\text { Ren. } \\
\text { Frac. }\end{array}$ & $\begin{array}{l}\text { Diesel } \\
(L)\end{array}$ & $\begin{array}{l}\text { Diesl } \\
\text { (hrs) }\end{array}$ \\
\hline 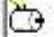 & 1500 & $\$ 570,000$ & $15,405,006$ & S $197,497,680$ & 5.671 & 0.00 & $2,167,728$ & 8,759 \\
\hline
\end{tabular}

(b)

\begin{tabular}{|c|c|c|c|c|c|c|c|c|c|c|c|}
\hline 4 田四 & $\begin{array}{c}\text { PV } \\
(\mathrm{kW})\end{array}$ & $\begin{array}{l}\text { Diesl } \\
(\mathrm{kW})\end{array}$ & 6FM200D & $\begin{array}{l}\text { Conv. } \\
(\mathrm{kW})\end{array}$ & $\begin{array}{l}\text { Initial } \\
\text { Capital }\end{array}$ & $\begin{array}{l}\text { Operating } \\
\text { Cost }(\$ / y r)\end{array}$ & $\begin{array}{l}\text { Total } \\
\text { NPC }\end{array}$ & $\begin{array}{c}\mathrm{COE} \\
(\$ / \mathrm{kWh})\end{array}$ & $\begin{array}{l}\text { Ren. } \\
\text { Frac. }\end{array}$ & $\begin{array}{l}\text { Diesel } \\
(\mathrm{L})\end{array}$ & $\begin{array}{l}\text { Diesl } \\
\text { (hrs) }\end{array}$ \\
\hline & 3500 & 500 & 3500 & 1000 & $\$ 9,980,000$ & $3,570,188$ & $\$ 55,618,984$ & 1.597 & 0.73 & 598,910 & 3,656 \\
\hline & 3500 & 500 & 3000 & 1000 & $\$ 9,080,000$ & $3,642,064$ & $\$ 55,637,796$ & 1.598 & 0.72 & 614,867 & 3,755 \\
\hline 7 F & 4000 & 500 & 3500 & 1000 & $\$ 10,350,000$ & $3,543,488$ & $\$ 55,647,672$ & 1.598 & 0.75 & 588,580 & 3,594 \\
\hline
\end{tabular}

(c)

\begin{tabular}{|c|c|c|c|c|c|c|c|c|c|c|}
\hline 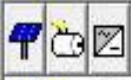 & $\begin{array}{c}\text { PV } \\
(\mathrm{kW})\end{array}$ & $\begin{array}{l}\text { Diesl } \\
(\mathrm{kW}) \\
\end{array}$ & $\begin{array}{l}\text { Conv. } \\
(\mathrm{kW})\end{array}$ & $\begin{array}{l}\text { Initial } \\
\text { Capital }\end{array}$ & $\begin{array}{l}\text { Operating } \\
\text { Cost (\$/yr) }\end{array}$ & $\begin{array}{l}\text { Total } \\
\text { NPC }\end{array}$ & $\begin{array}{c}\mathrm{COE} \\
(\$ / \mathrm{kWh})\end{array}$ & $\begin{array}{l}\text { Ren. } \\
\text { Frac. }\end{array}$ & $\begin{array}{c}\text { Diesel } \\
(\mathrm{L})\end{array}$ & $\begin{array}{l}\text { Diesl } \\
\text { (hrs) }\end{array}$ \\
\hline 0 & 4000 & 1500 & 1000 & $\$ 4,430,000$ & $9,698,021$ & $\$ 128,403,256$ & 3.687 & 0.66 & $1,367,729$ & 5,403 \\
\hline & 3500 & 1500 & 1000 & $\$ 4,060,000$ & $9,779,265$ & \$ $129,071,824$ & 3.706 & 0.62 & $1,382,201$ & 5,459 \\
\hline & 3000 & 1500 & 1000 & $\$ 3,690,000$ & $9,899,181$ & $\$ 130,234,768$ & 3.740 & 0.58 & $1,402,034$ & 5,537 \\
\hline
\end{tabular}

Fig. 3. Scenario energy systems based on software HOMER:

(a) Scenario 1: 100\% energy of diesel system; (b) Scenario 2: hybrid system combining diesel and solar energy with battery; (c) Scenario $3:$ hybrid system combining diesel and solar energy without battery.

The Scenario 1 uses $100 \%$ energy of diesel system. The advantage of using $100 \%$ diesel is its small initial capital required. It is USD 570000 . However, due to very high local price of diesel oil, its operating cost becomes very high, that is USD 15405006 per year. This causes very high value of NPC, which is USD 197497 680. The 
diesel is suitable to be implemented in a region with low local diesel prices. For the Maratua Island, using $100 \%$ diesel to fulfill the electricity demand can be problematic. Moreover, problems in diesel supply can disturb the powerplant. For the example, due to bad weather, diesel oil supply, which is transported through the sea, can be disrupted causing stop/blackout in the electricity system. The simulation result for Scenario 1 is shown in Fig. $3 \mathrm{a}$.

The Scenario 2 is the system combining the diesel and the solar energy with battery. The hybrid alternative with the lowest NPC is composed of the solar power with capacity of $3500 \mathrm{kWp}$, and diesel with a capacity of $500 \mathrm{~kW}$. The initial capital is USD 9980 000, annual operating cost is USD 3570 188, while total NPC value for this system is USD 55618 984, and the COE (Cost of Electricity) is USD 1.597/kWh. The price of COE is high because initial capital to build is still quite expensive. The simulation of this system is presented in Fig. $3 \mathrm{~b}$.

The Scenario 3 is the hybrid system that combines diesel and solar energy without battery. It is composed of solar power with capacity of $4000 \mathrm{kWp}$ and $1500 \mathrm{~kW}$ of diesel capacity. Its lowest total NPC for this system, which is USD 128403 256, is higher than that of the second but lower than that of Scenario 1. Its lowest initial capital, which is USD 4430 000, is lower than that of the second but higher than that of Scenario 1. Compared with the second scenario, the third one has larger value of the operating cost due to lack of the energy storage. In Scenario 3, when the solar power does not produce enough energy, the electricity demand will be supplied by the diesel. The result of HOMER simulation is presented by Fig. 3c.

The simulations showed that the use of diesel has the largest total NPC compared with the other two scenarios. The initial capital installation of the diesel is the lowest one, but the operating cost is the highest. Meanwhile, if the powerplant involves the renewable energy technology, the initial capital will rise, but the operating cost of the systems is decline. Optimization of power plant system needs to consider several important variables such as efficiency of the powerplant that will be implemented, the initial installation cost of the powerplant, the operation and maintenance cost, and renewable energy potential in the considered area.

This preliminary study needs to be followed up by a more in-depth verification and analysis to targeted level of electricity consumption and system configuration of photovoltaic electricity standard. Further analysis was required including electricity demand of public facilities and business infrastructure (tourism and others). This mentioned further study is required before next stage, i.e. basic design and detailed engineering design.

\section{Conclusion}

The hybrid system with a lowest total of NPC (USD 55618 984) is the system combining diesel power plant and photovoltaics with battery. It is composed of the photovoltaic with capacity of $3500 \mathrm{~kW}$ and diesel with a capacity of $500 \mathrm{~kW}$. The initial capital is USD 9980 000, while annual operating cost is USD 3570 188, and the COE is $1.597 \mathrm{USD} / \mathrm{kWh}$ which can saved up to $1568818 \mathrm{~L}$ of diesel oil in one cycle. Furthermore, comprehensive study is required before entering the next stage, i.e. basic design and detailed engineering design.

\section{References}

[1] Kabupaten Berau. Berau dalam angka 2013.[Berau in number 2013] Badan Pusat Statistik Kabupaten Berau. [Internet] Accesed on April $15^{\text {th }}, 2014$ from http://beraukab.bps.go.id/index.php?hal=publikasi_detil\&id=1. [Bahasa Indonesia]

[2] KKN PPM UGM Unit KTM 01 Maratua 2013. Pengembangan ekowisata serta penerapan prinsip education for sustainable development sebagai salah satu upaya pemberdayaan masyarakat pulau terluar Maratua, Kab. Berau, Kalimantan Timur [Ecotourism development and application of 'education for sustainable development' principle as community empowerment in Maratua, Berau District, East Kalimantan] Laporan KKN LPPM UGM. Yogyakarta; 2013. [Bahasa Indonesia].

[3] Provinsi Kalimantan Timur. Rasio desa berlistrik dan rasio elektrifikasi sampai tahun 2010 Kabupaten/Kodya di Provinsi Kalimantan Timur. [The ratio of electrified villages and electrification ratio in 2010 East Kalimantan Province] Dinas Pertambangan dan Energi Provinsi Kalimantan Timur. Samarinda; 2010. [Bahasa Indonesia]

[4] Robert. Derita internet kecamatan: listrik pas-pasan, solar kemahalan. [Suffered from internet district: mediocre power, yet expensive diesel fuel] Detik.com. [Internet] Accessed on May 13 ${ }^{\text {th }}, 2014$ from http://inet.detik.com/read/2013/09/25/094904/2368605/328/2/derita-internetkecamatan-listrik-pas-pasan-solar-kemahalan. [Bahasa Indonesia]

[5] DJK ESDM. Dirjen ketenagalistrikan resmikan PLTGU PT Bekasi Power di Cikarang. [DG of electricity inaugurates PT. Bekasi Power's combined cycle power plant in Cikarang] [Internet] Accesed on April 15 th 2014 from http://www.djlpe.esdm.go.id/modules/news/mbl_detail.php?news_id=3579. [Bahasa Indonesia] 
[6] NASA Langley ASDC User. NASA Surface Meteorology and Solar Energy: HOMER data; (n.d.)

[7] Yahya SY, Soeprapto, Utomo T. Analisis pembangkit listrik hibrida (plh), diesel dan energi terbarukan di pulau Mandangin, Sampang, Madura menggunakan software homer. [Analysis of hybrid power plants, diesel and renewable energy on the island Mandangin, Sampang, Madura using software homer] Jurnal Mahasiswa TEUB 2014;1:2. [Bahasa Indonesia]

[8] Schachinger M.. Module price index April 2014: little movement. [Internet] Accesed on May $13^{\text {th }}, 2014$ from: http://www.pvmagazine.com/investors/module-price-index/\#axzz31VYasdpJ.

[9] U.S. Energy Information Administration. Updated capital cost estimates for utility scale electricity generating plants. U.S. Department of Energy. Washington; 2013.

[10] Lambert T, Gilman P, Lilienthal P. Micropower system modeling with HOMER; 2006. 